\title{
Quality of Diabetes Care in Family Medicine Practices: Influence of Nurse-Practitioners and Physician's Assistants
}

\author{
Pamela A. Obman-Strickland, \\ $P b D^{1,2,3}$ \\ A. Jobn Orzano, MD, MPH ${ }^{2}$ \\ Shawna V. Hudson, $P b D^{2,3}$ \\ Leif I. Solberg, $M D^{4}$ \\ Barbara DiCiccio-Bloom, $\mathrm{PbD}^{2}$ \\ Dena O'Malley, BA² \\ Alfred F. Tallia, $M D, M P H^{2,3,5}$ \\ Bijal A. Balasubramanian, \\ $M B B S, M P H^{2}$
}

Benjamin F. Crabtree, $P b D^{2,3,5,6}$

'Department of Biostatistics, UMDNJSchool of Public Health, Piscataway, New Jersey

${ }^{2}$ Department of Family Medicine, UMDNJRobert Wood Johnson Medical School New Brunswick, New Jersey

${ }^{3}$ The Cancer Institute of New Jersey, UMDNJ-Robert Wood Johnson Medical School, New Brunswick, New Jersey

${ }^{4}$ HealthPartners Medical Group and HealthPartners Research Foundation, Minneapolis, Minnesota

${ }^{5}$ Center for Research in Family Practice and Primary Care, Cleveland, Ohio

${ }^{6}$ Department of Epidemiology, UMDNJSchool of Public Health, Piscataway, New Jersey

Conflicts of interest: none reported

\section{CORRESPONDING AUTHOR}

Pamela A. Ohman-Strickland, PhD

Department of Biostatistics UMDNJ-School of Public Health

683 Hoes Ln W, Room 218

PO Box 9

Piscataway, NJ 08854

ohmanpa@umdnj.edu

\begin{abstract}
PURPOSE The aim of this study was to assess whether the quality of diabetes care differs among practices employing nurse-practitioners (NPs), physician's assistants $(\mathrm{PAs})$, or neither, and which practice attributes contribute to any differences in care.

METHODS This cross-sectional study of 46 family medicine practices from New Jersey and Pennsylvania measured adherence to American Diabetes Association diabetes guidelines via chart audits of 846 patients with diabetes. Practice characteristics were identified by staff surveys. Hierarchical models determined differences between practices with and without NPs or PAs.
\end{abstract}

RESULTS Compared with practices employing PAs, practices employing NPS were more likely to measure hemoglobin $A_{1 c}$ levels (66\% vs $33 \%$ ), lipid levels ( $80 \%$ vs $58 \%$ ), and urinary microalbumin levels (32\% vs $6 \%$ ); to have treated for high lipid levels (77\% vs $56 \%$ ); and to have patients attain lipid targets ( $54 \%$ vs $37 \%)(P \leq .005$ for each). Practices with NPs were more likely than physician-only practices to assess hemoglobin $A_{1 c}$ levels (66\% vs $49 \%$ ) and lipid levels ( $80 \%$ vs $68 \%)(P \leq .007$ for each). These effects could not be attributed to use of diabetes registries, health risk assessments, nurses for counseling, or patient reminder systems. Practices with either PAs or NPs were perceived as busier $(P=.03)$ and had larger total staff $(P<.001)$ than physician-only practices.

CONCLUSIONS Family practices employing NPs performed better than those with physicians only and those employing PAs, especially with regard to diabetes process measures. The reasons for these differences are not clear.

Ann Fam Med 2008;6:14-22. DOI: 10.1370/afm.758.

\section{INTRODUCTION}

I ncreasingly, nurse-practitioners (NPs) and physician's assistants (PAs) serve as a primary point of contact for patients within primary care practices ${ }^{1,2}$ Bolstering this trend is the development of new models of primary care practice advocating collaborative teams of diverse clinicians. $^{3-5}$ Yet, among family physicians, some uncertainty and unease persists about the use of these clinicians, ${ }^{6-8}$ particularly with regard to quality of care, ${ }^{9,10}$ patient satisfaction, ${ }^{11,12}$ and financial efficiency. ${ }^{13,14}$

Most randomized clinical trials and observational studies have focused on comparing the quality of care between physicians and NPs, with relatively little published research comparing PAs with either physicians or NPs. ${ }^{9}, 15-18$ For example, in a study comparing NP and physician performance in the care and attainment of outcomes for patients with diabetes, Lenz et a ${ }^{19}$ found significant differences in documentation but not in patient outcomes. Some have argued that NPs may enhance primary care because they are trained specifically for health promotion and education. ${ }^{2,20,21}$ In fact, Hopkins et al ${ }^{22}$ found that compared with physicians, NPs performed better at secondary prevention, assessment, and counseling. In addition, Kinnersely et $\mathrm{al}^{15}$ and 
Sakr et $a{ }^{16}$ found that patients cared for by NPs received more information about their care and were less likely to return for follow-up advice. Regarding self-reported patient satisfaction, studies have found no significant differences whether care was provided by NPs (or PAs) or physicians. ${ }^{11,12}$ The literature thus suggests some benefits of care provided by NPs, potentially making these clinicians more than just adequate substitutes during physician shortages. Since NP and PA salaries are generally less than those of physicians, this literature suggests that practices using NPs or PAs could potentially provide quality care at lower cost to the practice ${ }^{13,23}{ }_{i}$ however, differences in productivity and patient mix and needs for supervision and backup may negate this benefit. A recent Cochrane review reported that most studies have not found significant cost differences. ${ }^{24}$

These studies have compared care provided by individual clinicians (physician, PA, or NP) by directly linking individual patients with the type of clinician ${ }^{15-}$ 17,23 or by comparing care provided by practices solely staffed by either physicians or NPs. ${ }^{9}$ Evidence suggests, however, that care quality needs to be viewed from a systems perspective and according to the interrelationships among individuals, not simply from the perspective of specific individuals. ${ }^{25-27}$ Whereas evidence thus exists that NPs and PAs are capable of providing quality care, this capability does not necessarily imply they are used effectively when added to the typical primary care practice. Rather than focusing on individual skill sets, this study therefore examined the effectiveness of practices employing different midlevel clinicians to better understand at a practice level the effect of NPs and PAs on quality of care; furthermore, because of the complexity of managing patients with diabetes in primary care practices, ${ }^{28-30}$ this study focused on care for these patients. Specifically, the study's objectives were to evaluate (1) whether the quality of care provided to patients with diabetes differs between practices with and without PAs or NPs and (2) whether the organizational characteristics of practices with PAs or NPs differ from those without such clinicians.

\section{METHODS}

\section{Study Design}

This study was a secondary, cross-sectional analysis of the baseline data from a quality improvement trial in family medicine practices. After the study was approved by the institutional review board of the University of Medicine and Dentistry of New Jersey, baseline data were collected from 46 New Jersey and Pennsylvania nonresidency family medicine practices participating in ULTRA (Using Learning Teams for Reflective Adaptation), a group randomized intervention study ${ }^{31}$ aimed at testing a method for improving practice adherence to guidelines for multiple conditions. These independent, small group or solo, single-specialty family medicine practices included 28 practices with neither a PA nor an NP on staff (physician-only practices), 9 practices with 1 or more PAs, and 9 practices with 1 or 2 NPs. Two practices with both PAs and NPs were excluded.

Nurse chart auditors retrospectively assessed each practice's adherence to diabetes guidelines in 20 patients randomly selected from all adults treated for type 1 or type 2 diabetes in the past year, based on International Classification of Diseases, Ninth Revision (ICD-9) codes 250.xx. In 6 practices with fewer than 20 patients coded for diabetes, all of these charts were audited. In total, 846 patients' charts were audited.

Basic information concerning each practice was collected from the practice manager or lead physician using a standardized Practice Information Form (PIF), described below. In addition, all practice staff were given a questionnaire that included the Survey of Organizational Attributes for Primary Care (SOAPC) ${ }^{32}$ and the Competing Values Framework (CVF), ${ }^{33,34}$ also described below. Questionnaires were collected by the practice manager and returned to a member of the research team.

\section{Measures}

We used the audits of medical records to assess adherence to guidelines for diabetes care, adapted from the clinical practice guidelines of the American Diabetes Association (ADA), ${ }^{35}$ in the areas of assessment, treatment, and achievement of clinical targets. These measures, which are mostly process measures, are presented in Table 1. Practice adherence to the assessment

\section{Table 1. Description of Dependent Variables: Components of Diabetes Guidelines}

Assessment

$\mathrm{HbA}_{1 \mathrm{c}}$ test in the last 6 months

LDL-cholesterol test in the last 12 months

Microalbumin test in the last 12 months

BP check at every visit

Treatment

$\mathrm{HbA}_{\mathrm{c}} \leq 8 \%$, or $>8 \%$ and on a hypoglycemic agent

LDL-cholesterol $\leq 100 \mathrm{mg} / \mathrm{dL}$, or $>100 \mathrm{mg} / \mathrm{dL}$ and on a lipidlowering agent

$\mathrm{BP} \leq 130 / 85 \mathrm{~mm} \mathrm{Hg}$, or $>130 / 85 \mathrm{~mm} \mathrm{Hg}$ and on an antihypertensive agent

Microalbumin in urine $>30 \mathrm{mg}$ in $24 \mathrm{hr}$ and on an ACE inhibitor or ARB

Target attainment

$\mathrm{HbA}_{1 \mathrm{c}} \leq 7 \%$

LDL-cholesterol $\leq 100 \mathrm{mg} / \mathrm{dL}$

$\mathrm{BP} \leq 130 / 85 \mathrm{~mm} \mathrm{Hg}$

$\mathrm{HbA}_{1 \mathrm{c}}=$ hemoglobin $\mathrm{A}_{1 \mathrm{c}}$ LDL = low-density lipoprotein; $\mathrm{BP}=$ blood pressure; $A C E=$ angiotensin-converting enzyme; $A R B=$ angiotensin receptor blocker. 
component of the guidelines was studied in all patients, whereas practice adherence to the treatment and target components of the guidelines was studied using 2 populations: (1) all patients with diabetes and (2) only patients with diabetes who were appropriately assessed In both populations, credit for adhering to treatment guidelines was given if the patient was appropriately treated or if evidence of achieving targets existed (as determined by assessments within the recommended time frame). In the latter case, we assumed there may have been alternative treatment strategies that aided the patient in achieving targets. In both populations, credit for adhering to target guidelines was given only if evidence existed that the patient had achieved the targets. Analyses of practice adherence included several patient-level and practice-level covariates, described below.

The practice manager or lead physician from each practice completed a PIF, which provided the following information: a list of staff members and their roles; whether the practice was a solo or group practice, whether the practice had a diabetes registry; whether the practice used patient reminder systems $;$ and whether nurses or health educators were used for counseling for diabetes, physical activity, nutrition, or tobacco.

Staff members completed a 20-minute, self-administered questionnaire that included the SOAPC $^{32}$ and the CVF. ${ }^{33,34}$ Of 732 staff members, 452 (62\%) returned the questionnaire, with 95\% of those completing the SOAPC and $98 \%$ completing the CVF. The SOAPC assessed levels of busyness, practicewide participation in decision making, nurses' participation in decision making, communication, and history of change. Each item (Table 2) was rated on a scale of 1 (strongly disagree) to 5 (strongly agree). To obtain staff scores, we averaged the responses for each domain, reverse-scoring items that were negatively worded. To obtain scores for the practice overall, we averaged the staff scores. The CVF allowed for description of each practice as more or less group oriented, developmental, hierarchical, or market driven, allowing us to study whether practices with NPs or PAs were more or less market driven than other practices. We used the $6 \mathrm{CVF}$ items that pertain to market orientation (Table 2). We applied the scoring method outlined by Quinn ${ }^{33}$ to obtain staff and practice-averaged ratings of a practice's market orientation and then dichotomized the practice score (market driven vs not market driven) relative to the sample median.

\section{Statistical Analyses}

We used univariate analyses, including exact $\chi^{2}$ tests for categorical descriptors and analysis of variance for continuous descriptors, to compare the characteristics of the 3 types of practices.
Table 2. Items From the Survey of Organizational Attributes for Primary Care (SOAPC) ${ }^{32}$ and the Competing Values Framework (CVF) ${ }^{34}$

\section{SOAPC items}

Communication

1. When there is a conflict in this practice, the people involved usually talk it out and resolve the problem successfully.

2. Our staff has constructive work relationships.

3. There is often tension between people in this practice.

4. The staff and clinicians in this practice operate as a real team.

Practicewide decision making

5. This practice encourages staff input for making changes and improvements.

6. All of the staff participates in important decisions about the clinical operation.

7. The practice defines success as teamwork and concern for people.

8. Staff are involved in developing plans for improving quality.

Nurses' participation in decision making

9. This practice encourages nursing and clinical staff input for making changes and improvements.

10. Practice leadership discourages nursing staff from taking initiative. Busyness

11. It's hard to make any changes in this practice because we're so busy seeing patients.

12. The staff members of this practice very frequently feel overwhelmed by the work demands.

13. The clinicians in this practice very frequently feel overwhelmed by the work demands.

14. Practice experienced as "stressful."

15. This practice is almost always in chaos.

16. Things have been changing so fast in our practice that it is hard to keep up with what is going on.

History of change

17. Our practice has changed in how it takes initiative to improve patient care.

18. Our practice has changed in how it does business.

19. Our practice has changed in how everyone relates.

CVF items pertaining to market orientation

1. The practice is a very controlled and structured place. Formal procedures generally govern what people do.

2. The leadership in the practice is generally considered to exemplify coordinating, organizing, or smooth-running efficiency.

3. The management style in the practice is characterized by security of employment, conformity, predictability, and stability in relationships.

4. The glue that holds the practice together is formal rules and policies. Maintaining a smoothrunning organization is important.

5. The practice emphasizes permanence and stability. Efficiency, control, and smooth operations are important.

6. The practice defines success on the basis of efficiency. Dependable delivery, smooth scheduling, and low-cost production are critical. 
We used hierarchical logistic regression analysis to model associations between the presence of PAs or NPs in practices and patient-level measures of diabetes assessment, treatment, and target attainment, accounting for clustering of patients within practice while controlling for both practice-level covariates (solo practice or not, diabetes registry, nurse or health educator for diabetes counseling, reminder system, total staff size) and patient-level covariates (age, sex, comorbid conditions, number of visits in last 2 years). Specifically, generalized estimating equations using a working correlation matrix with exchangeable structure modeled the log-odds of adherence as a function of practice- and patient-level covariates, using the GENMOD procedure within the SAS/STAT software (SAS system for Windows, version 9.1.3; SAS Institute Inc, Cary, North Carolina). ${ }^{36}$ We used contrasts to examine differences between practice types and to calculate adjusted rates of adherence. The false-discovery rate was controlled at .05 via the Hochberg procedure for multiple testing ${ }^{37}$ within each domain (assessment, treatment, and targets).

Additional analyses compared organizational attributes (as measured by the SOAPC) of practices with and without PAs or NPs at both the practice level and staff level. For the former, analysis of covariance compared the average practice scores. For the latter, hierarchical models, with staff member as the unit of observation, were used to test differences in how staff members perceived the practice in which they worked as a function of practice type (physician-only, PA, NP), controlling for practice size and staff member covariates including role (office manager, physician, PA, NP, clinical staff, or office staff) and sex. We used similar analyses, applying a logit link for binary responses, to evaluate whether practice type could predict whether the practice was more or less market driven (as determined from the CVF). Imputation methods were used to adjust for survey nonresponse. Specifically, we used sequential multivariate regression models (logistic, Poisson, or categorical, depending on the dependent variable type) to multiply impute the missing data $^{38}$ using IVEware (University of Michigan Survey Research Center, Ann Arbor, Michigan), an SAS callable software application. ${ }^{39}$ Standard errors for means or comparisons of means were corrected using standard multiple imputation adjustments.

\section{RESULTS}

\section{Practice Characteristics}

Thirteen of 17 PAs and all of the 9 NPs were women. PAs had worked at their current practice for shorter times relative to NPs, although this difference was not statistically significant $(P=.11$ based on analysis of variance using listwise deletion).

Table 3 summarizes practice characteristics for the

\begin{tabular}{|c|c|c|c|c|c|}
\hline Characteristic & $\begin{array}{c}\text { Practices } \\
\text { With NPs } \\
(n=9)\end{array}$ & $\begin{array}{c}\text { Practices } \\
\text { With PAs } \\
(n=9)\end{array}$ & $\begin{array}{l}\text { Practices With } \\
\text { Physicians Only } \\
(n=28)\end{array}$ & $P$ Value & $\begin{array}{c}\text { Total } \\
\text { or Mean } \\
(\mathrm{N}=46)\end{array}$ \\
\hline \multicolumn{6}{|l|}{ Practice classification ${ }^{a}$} \\
\hline \multicolumn{6}{|l|}{ Number of physicians } \\
\hline 1 & $1(11.1)$ & $0(0)$ & $8(28.6)$ & .02 & 9 \\
\hline $2-4$ & $8(88.9)$ & $4(44.4)$ & $15(53.6)$ & & 27 \\
\hline $5-8$ & $0(0)$ & $5(55.6)$ & $5(17.9)$ & & 10 \\
\hline Has a diabetes registry & $1(11.1)$ & $4(44.4)$ & $3(10.7)$ & .08 & 8 \\
\hline $\begin{array}{l}\text { Uses nurses or health educators for diabetes } \\
\text { counseling }\end{array}$ & $2(22.2)$ & $2(22.2)$ & $8(28.6)$ & 1.00 & 12 \\
\hline Counsels for physical activity, eating, and tobacco & $1(11.1)$ & $0(0)$ & $2(7.1)$ & 1.00 & 3 \\
\hline Counsels for physical activity or eating or tobacco & $1(11.1)$ & $1(11.1)$ & $5(17.9)$ & 1.00 & 7 \\
\hline $\begin{array}{l}\text { Performs health risk assessment for physical activity, } \\
\text { eating, and tobacco }\end{array}$ & $0(0)$ & $2(22.2)$ & $7(25.0)$ & .33 & 9 \\
\hline $\begin{array}{l}\text { Performs health risk assessment for physical activity } \\
\text { or eating or tobacco }\end{array}$ & $0(0)$ & $6(66.7)$ & $13(46.4)$ & .18 & 19 \\
\hline Has a reminder system & $6(66.7)$ & $5(55.6)$ & $15(53.6)$ & .91 & 26 \\
\hline \multicolumn{6}{|l|}{ Practice staff summary } \\
\hline Total number of staff & $13.7(4.4)$ & $30.0(10.8)$ & $12.1(9.4)$ & $<.001$ & $15.9(11.3)$ \\
\hline Number of NPs or PAs & $1.1(0.3)$ & $1.9(1.1)$ & $0(0)$ & .02 & $0.6(0.5)$ \\
\hline Proportion of NPs or PAs & $8.8(3.1)$ & $6.1(2.4)$ & $0(0)$ & $.13^{c}$ & $2.9(3.4)$ \\
\hline
\end{tabular}


3 practice types. Practices with PAs were more likely to have a larger total staff $(P<.001)$. Eight practices had only $1 \mathrm{NP}$ and 1 had $2 \mathrm{NPs}_{\text {; }}$ however, 4 practices had 1 PA whereas 5 had between 2 and 4 . The number of NPs or PAs per physician did not differ significantly among practices. On the basis of the information available from the staff questionnaires (from 20 physician-only practices, 6 practices with PAs, and 6 practices with NPs), physicians at the 3 types of practices were statistically indistinguishable with respect to sex, age, race, years at the practice, and average mean hours worked per week.

Across the 3 practice types, patients with diabetes did not differ significantly in terms of sex, age, and comorbidities (Table 4). Overall, one-half of patients were male, and the average age was 60 years. Two-thirds had coronary artery disease, hypertension, or both.

\section{Quality of Diabetes Care Among Practices}

We compared the quality of diabetes care (1) between practices with NPs and those with PAs, (2) between practices with NPs and physician-only practices, and (3) between practices with PAs and physician-only practices (Table 5).

Practices With NPs vs Practices With PAs Compared with practices with PAs, practices with NPs were almost twice as likely to assess hemoglobin $\mathrm{A}_{1 \mathrm{c}}\left(\mathrm{HbA}_{1 \mathrm{c}}\right)$ levels $(P=.005)$, were $37 \%$ more likely to assess lipid levels $(P=.004)$, and were more than 5 times as likely to assess microalbumin levels $(P<.001)$ (Table 5). Practices with NPs were also 37\% more likely to meet treatment guidelines for lipids (credit given if assessed appropriately and within target or if treated according to guidelines) $(P=.004)$ and were $45 \%$ more likely to have patients attain lipid targets (if not assessed, it is assumed a patient was not at target) $(P=.001)$. These results for lipids retained marginal significance even when patients who were not assessed were eliminated from the analyses. Although not significant, the rate ratio comparing treatment for the microalbumin measure between NP and PA practices was similar to that for lipids.

Practices With NPs vs Practices With Physicians Only Compared with physician-only practices, practices with NPs were $34 \%$ more likely to assess $\mathrm{HbA}_{1 \mathrm{c}}$ levels $(P<.001)$ and $17 \%$ more likely to assess lipid levels $(P=.007)$ (Table 5). The assessment rate for microalbumin was higher among practices with NPs as well, although not significantly so.

Practices With PAs vs Practices With Physicians Only Compared with physician-only practices, practices with PAs were $67 \%$ less likely to assess microalbumin levels $(P=.02)$ (Table 5). Although the difference was not significant, they were also $32 \%$ and $15 \%$ less likely to assess $\mathrm{HbA}_{1 \mathrm{c}}$ and lipid levels, respectively. Additionally, practices with PAs were $32 \%$ less likely than physician-only practices to have patients attain lipid targets $(P<.001)$, a relationship that held even when nonassessed patients were eliminated from analyses.

\section{Organizational Attributes and Market Orientation of Practices}

We found little difference in the organizational attributes and market orientation of practices with or without PAs or NPs (Table 6). Physician-only practices were somewhat less busy than practices with either PAs or NPs $(P=.03)$. These results remained similar after adjusting for potential confounders and when considering just clinician responses.

\section{DISCUSSION}

Family medicine practices employing NPs significantly outperformed practices employing PAs in key ADA-

Table 4. Comparison of Characteristics of Diabetic Patients Across Practices

\begin{tabular}{|c|c|c|c|c|c|}
\hline Characteristic & $\begin{array}{l}\text { Practices With NPs } \\
\qquad(\mathrm{n}=9)\end{array}$ & $\begin{array}{l}\text { Practices With PAs } \\
\qquad(\mathrm{n}=9)\end{array}$ & $\begin{array}{l}\text { Practices With } \\
\text { Physicians Only } \\
\quad(n=28)\end{array}$ & $P$ Value $^{a}$ & $\begin{array}{l}\text { Overall } \\
(N=46)\end{array}$ \\
\hline Male, \% & $49.1(16.3)$ & $51.3(13.4)$ & $48.3(14.8)$ & .87 & $49.1(14.5)$ \\
\hline Age, mean years & $62.7(5.3)$ & $59.6(5.9)$ & $59.9(4.8)$ & .31 & $60.4(5.1)$ \\
\hline \multicolumn{6}{|l|}{ Comorbidity, \% } \\
\hline No CAD or hypertension & $29.9(13.2)$ & $44.6(21.0)$ & $31.3(13.3)$ & .06 & $33.6(15.7)$ \\
\hline CAD only & $7.8(9.7)$ & $3.9(6.0)$ & $4.2(4.7)$ & .29 & $4.8(6.2)$ \\
\hline Hypertension only & $48.3(23.3)$ & $42.6(17.7)$ & $55.3(13.6)$ & .12 & $51.4(17.0)$ \\
\hline CAD and hypertension & $14.0(10.8)$ & $8.9(7.4)$ & $9.2(10.4)$ & .43 & $10.1(10.0)$ \\
\hline
\end{tabular}




\begin{tabular}{|c|c|c|c|c|c|c|c|}
\hline \multirow[b]{2}{*}{ Measure } & \multirow[b]{2}{*}{$\begin{array}{l}\text { Total No. } \\
\text { of Patients }\end{array}$} & \multicolumn{3}{|c|}{$\%(95 \% \mathrm{Cl})$} & \multicolumn{3}{|c|}{$\begin{array}{c}\text { Pairwise Comparison, } \\
\text { Rate Ratio ( } P \text { Value) }\end{array}$} \\
\hline & & $\begin{array}{c}\text { Practices } \\
\text { With NPs } \\
(n=9)\end{array}$ & $\begin{array}{c}\text { Practices } \\
\text { With PAs } \\
(n=9)\end{array}$ & $\begin{array}{l}\text { Practices With } \\
\text { Physicians Only } \\
(n=28)\end{array}$ & $\begin{array}{c}\text { NP } \\
\text { vs PA }\end{array}$ & $\begin{array}{l}\text { NP vs } \\
\text { Physician- } \\
\text { Only }\end{array}$ & $\begin{array}{c}\text { PA vs } \\
\text { Physician- } \\
\text { Only }\end{array}$ \\
\hline \multicolumn{8}{|l|}{ Assessed (all patients) } \\
\hline $\mathrm{HbA}_{\mathrm{cc}}$ in last 6 months & 846 & $\begin{array}{c}65.5 \\
(57.7-72.5)\end{array}$ & $\begin{array}{c}33.4 \\
(17.9-53.4)\end{array}$ & $\begin{array}{c}48.9 \\
(36.8-61.2)\end{array}$ & $\begin{array}{l}1.96 \\
(.005)^{\mathrm{a}}\end{array}$ & $\begin{array}{c}1.34 \\
(<.001)^{\mathrm{a}}\end{array}$ & $\begin{array}{l}0.68 \\
(.21)\end{array}$ \\
\hline $\mathrm{BP}$ at last 3 visits & 846 & $\begin{array}{c}80.1 \\
(64.1-90.0)\end{array}$ & $\begin{array}{c}75.0 \\
(47.5-90.8)\end{array}$ & $\begin{array}{c}83.2 \\
(74.3-89.4)\end{array}$ & $\begin{array}{l}1.06 \\
(.72)\end{array}$ & $\begin{array}{l}0.96 \\
(.63)\end{array}$ & $\begin{array}{l}0.90 \\
(.50)\end{array}$ \\
\hline Lipids in last 12 months & 846 & $\begin{array}{c}80.1 \\
(72.6-86.0)\end{array}$ & $\begin{array}{c}58.2 \\
(45.4-69.9)\end{array}$ & $\begin{array}{c}68.3 \\
(55.3-78.9)\end{array}$ & $\begin{array}{l}1.37 \\
(.004)^{\mathrm{a}}\end{array}$ & $\begin{array}{l}1.17 \\
(.007)^{\mathrm{a}}\end{array}$ & $\begin{array}{l}0.85 \\
(.29)\end{array}$ \\
\hline $\begin{array}{l}\text { Microalbumin in last } \\
12 \text { months }\end{array}$ & 846 & $\begin{array}{c}31.9 \\
(14.1-57.1)\end{array}$ & $\begin{array}{c}6.1 \\
(2.7-13.3)\end{array}$ & $\begin{array}{c}18.6 \\
(10.8-30.1)\end{array}$ & $\begin{array}{l}5.26 \\
(<.001)^{\mathrm{a}}\end{array}$ & $\begin{array}{l}1.72 \\
(.10)\end{array}$ & $\begin{array}{l}0.33 \\
(.02)^{\mathrm{a}}\end{array}$ \\
\hline \multicolumn{8}{|l|}{$\begin{array}{l}\text { Treated or assessed and } \\
\text { at target (all patients) }\end{array}$} \\
\hline $\mathrm{HbA}_{1 c}$ unadjusted $^{c}$ & 846 & 98.2 & 99.4 & 100.0 & NA & NA & NA \\
\hline $\mathrm{BP}$ & 846 & $\begin{array}{c}76.1 \\
(61.4-86.5)\end{array}$ & $\begin{array}{c}81.5 \\
(72.7-87.9)\end{array}$ & $\begin{array}{c}78.3 \\
(69.5-85.2)\end{array}$ & $\begin{array}{l}0.93 \\
(.48)\end{array}$ & $\begin{array}{l}0.97 \\
(.72)\end{array}$ & $\begin{array}{l}1.04 \\
(.58)\end{array}$ \\
\hline Lipids & 846 & $\begin{array}{c}76.6 \\
(66.6-84.4)\end{array}$ & $\begin{array}{c}55.9 \\
(43.4-67.8)\end{array}$ & $\begin{array}{c}65.7 \\
(60.1-71.0)\end{array}$ & $\begin{array}{l}1.37 \\
(.004)^{\mathrm{a}}\end{array}$ & $\begin{array}{l}1.17 \\
(.03)\end{array}$ & $\begin{array}{l}0.85 \\
(.20)\end{array}$ \\
\hline Microalbumin & 846 & $\begin{array}{c}79.6 \\
(61.7-90.5)\end{array}$ & $\begin{array}{c}61.4 \\
(34.7-82.6)\end{array}$ & $\begin{array}{c}65.7 \\
(53.5-76.1)\end{array}$ & $\begin{array}{l}1.30 \\
(.26)\end{array}$ & $\begin{array}{l}1.21 \\
(.11)\end{array}$ & $\begin{array}{l}0.93 \\
(.79)\end{array}$ \\
\hline \multicolumn{8}{|l|}{$\begin{array}{l}\text { Treated or at target } \\
\text { (only if assessed) }\end{array}$} \\
\hline $\mathrm{HbA}_{1 c}$ unadjusted & 439 & 100.0 & 100.0 & 100.0 & NA & NA & NA \\
\hline $\mathrm{BP}$ & 653 & $\begin{array}{c}78.0 \\
(63.9-87.7)\end{array}$ & $\begin{array}{c}81.8 \\
(72.3-88.5)\end{array}$ & $\begin{array}{c}79.0 \\
(71.1-85.3)\end{array}$ & $\begin{array}{l}0.95 \\
(.63)\end{array}$ & $\begin{array}{l}0.99 \\
(.86)\end{array}$ & $\begin{array}{l}1.04 \\
(.64)\end{array}$ \\
\hline Lipids & 566 & $\begin{array}{c}77.2 \\
(65.3-85.9)\end{array}$ & $\begin{array}{c}64.7 \\
(52.2-75.5)\end{array}$ & $\begin{array}{c}72.0 \\
(62.8-79.7)\end{array}$ & $\begin{array}{l}1.19 \\
(.09)\end{array}$ & $\begin{array}{l}1.07 \\
(.32)\end{array}$ & $\begin{array}{l}0.90 \\
(.37)\end{array}$ \\
\hline Microalbumin & 166 & $\begin{array}{c}98.2 \\
(92.8-99.6)\end{array}$ & $\begin{array}{c}86.4 \\
(45.4-98.0)\end{array}$ & $\begin{array}{c}97.7 \\
(87.5-99.6)\end{array}$ & $\begin{array}{l}1.13 \\
(.07)\end{array}$ & $\begin{array}{l}1.01 \\
(.71)\end{array}$ & $\begin{array}{l}0.88 \\
(.09)\end{array}$ \\
\hline \multicolumn{8}{|l|}{$\begin{array}{l}\text { Assessed and at target } \\
\text { (all patients) }\end{array}$} \\
\hline $\mathrm{HbA}_{1 \mathrm{c}}$ & 846 & $\begin{array}{c}50.7 \\
(37.3-64.0)\end{array}$ & $\begin{array}{c}48.6 \\
(34.6-62.8)\end{array}$ & $\begin{array}{c}44.5 \\
(36.5-52.7)\end{array}$ & $\begin{array}{l}1.04 \\
(.84)\end{array}$ & $\begin{array}{l}1.14 \\
(.36)\end{array}$ & $\begin{array}{l}1.09 \\
(.63)\end{array}$ \\
\hline $\mathrm{BP}$ & 846 & $\begin{array}{c}36.5 \\
(25.0-49.8)\end{array}$ & $\begin{array}{c}45.0 \\
(31.5-59.2)\end{array}$ & $\begin{array}{c}47.3 \\
(36.9-58.0)\end{array}$ & $\begin{array}{l}0.81 \\
(.44)\end{array}$ & $\begin{array}{l}0.77 \\
(.13)\end{array}$ & $\begin{array}{l}0.95 \\
(.35)\end{array}$ \\
\hline Lipids & 846 & $\begin{array}{c}53.5 \\
(45.0-61.8)\end{array}$ & $\begin{array}{c}36.8 \\
(30.8-43.1)\end{array}$ & $\begin{array}{c}54.4 \\
(49.0-59.8)\end{array}$ & $\begin{array}{l}1.45 \\
(.001)^{\mathrm{a}}\end{array}$ & $\begin{array}{l}0.98 \\
(.85)\end{array}$ & $\begin{array}{l}0.68 \\
(<.001)^{\mathrm{a}}\end{array}$ \\
\hline \multicolumn{8}{|l|}{ At target (only if assessed) ${ }^{f}$} \\
\hline $\mathrm{HbA}_{1 \mathrm{c}}$ & 439 & $\begin{array}{c}52.9 \\
(41.9-63.6)\end{array}$ & $\begin{array}{c}54.5 \\
(35.7-72.2)\end{array}$ & $\begin{array}{c}59.0 \\
(50.5-67.1)\end{array}$ & $\begin{array}{l}0.97 \\
(.89)\end{array}$ & $\begin{array}{l}0.90 \\
(.34)\end{array}$ & $\begin{array}{l}0.92 \\
(.69)\end{array}$ \\
\hline $\mathrm{BP}$ & 653 & $\begin{array}{c}37.7 \\
(24.2-53.3)\end{array}$ & $\begin{array}{c}45.8 \\
(31.8-60.6)\end{array}$ & $\begin{array}{c}46.0 \\
(36.1-56.3)\end{array}$ & $\begin{array}{l}0.83 \\
(.51)\end{array}$ & $\begin{array}{l}0.82 \\
(.32)\end{array}$ & $\begin{array}{l}1.00 \\
(.98)\end{array}$ \\
\hline Lipids & 566 & $\begin{array}{c}47.5 \\
(38.6-56.7)\end{array}$ & $\begin{array}{c}35.6 \\
(27.5-44.5)\end{array}$ & $\begin{array}{c}48.9 \\
(41.4-56.5)\end{array}$ & $\begin{array}{l}1.33 \\
(.047)\end{array}$ & $\begin{array}{l}0.97 \\
(.78)\end{array}$ & $\begin{array}{l}0.73 \\
(.04)\end{array}$ \\
\hline
\end{tabular}

$\mathrm{Cl}=$ confidence interval; $\mathrm{NP}=$ nurse-practitioner; $\mathrm{PA}=$ physician's assistant; $\mathrm{HbA}_{1 \mathrm{c}}=$ hemoglobin $\mathrm{A}_{1 \mathrm{c}} ; \mathrm{BP}=$ blood pressure; $\mathrm{NA}=$ not applicable.

Note: Probabilities were adjusted for patient-level covariates (age, sex, comorbid conditions, number of visits in last 2 years) and practice-level covariates (solo practice or not, diabetes registry, nurse or health educator for diabetes counseling, reminder system, total staff size).

a Significant after controlling the false-discovery rate at .05 via the Hochberg procedure for multiple testing.

${ }^{b}$ Credit given if assessed appropriately and within target, or if treated according to guidelines.

' Because rates of treatment were so high, models could not differentiate the effects of NP or PA practice type after accounting for additional patient and practice covariates.

${ }^{d}$ Includes only patients who were assessed; credit given if at target or treated according to guidelines.

e Credit given if assessed appropriately and within target.

${ }^{\mathrm{f}}$ Includes only patients who were assessed; credit given if at target. 


\begin{tabular}{|c|c|c|c|c|c|}
\hline \multirow[b]{2}{*}{ Measure } & \multirow{2}{*}{$\begin{array}{l}\text { Practices } \\
\text { With NPs } \\
(n=9)\end{array}$} & \multirow{2}{*}{$\begin{array}{l}\text { Practices } \\
\text { With PAs }^{\mathrm{a}} \\
(\mathrm{n}=9)\end{array}$} & \multirow{2}{*}{$\begin{array}{l}\text { Practices With } \\
\text { Physicians Onlya } \\
(n=28)\end{array}$} & \multicolumn{2}{|c|}{$\begin{array}{l}\text { Minimum Pairwise } \\
\text { Adjusted } P \text { Value }\end{array}$} \\
\hline & & & & Practice Level $^{b}$ & Staff Levelc \\
\hline \multicolumn{6}{|l|}{ Organizational attributes, mean (SEM) } \\
\hline \multirow[t]{2}{*}{ Busyness } & $3.16^{d}$ & 3.18 & $2.66^{d}$ & $.03^{d}$ & $.04^{\mathrm{d}}$ \\
\hline & $(0.20)$ & $(0.20)$ & $(0.12)$ & & \\
\hline \multirow[t]{2}{*}{ Practicewide decision making } & 3.31 & 3.06 & 3.48 & .55 & .28 \\
\hline & $(0.21)$ & $(0.20)$ & $(0.12)$ & & \\
\hline \multirow{2}{*}{$\begin{array}{l}\text { Participation of nurses in decision } \\
\text { making }\end{array}$} & 3.71 & 3.49 & 3.79 & .82 & .66 \\
\hline & $(0.19)$ & $(0.17)$ & $(0.11)$ & & \\
\hline \multirow[t]{2}{*}{ Communication } & 3.30 & 3.02 & 3.57 & .31 & .21 \\
\hline & $(0.21)$ & $(0.20)$ & $(0.12)$ & & \\
\hline \multirow[t]{2}{*}{ Change } & 3.03 & 3.24 & 3.01 & .68 & .22 \\
\hline & $(0.16)$ & $(0.17)$ & $(0.10)$ & & \\
\hline Market orientation, No. (\%) & $3(33)$ & $6(67)$ & $14(50)$ & .26 & .24 \\
\hline \multicolumn{6}{|c|}{$\mathrm{NP}=$ nurse-practitioner; $\mathrm{PA}=$ physician's assistant; $\mathrm{SEM}=$ standard error of the mean. } \\
\hline \multicolumn{6}{|c|}{$\begin{array}{l}\text { Note: Organizational attributes are expressed as mean (SEM) scores on scales ranging from } 1 \text { to } 5 \text {, where higher scores indicate stronger staff endorsement of the attr } \\
\text { bute; market orientation is expressed as the No. (\%) of practices that had above-median staff ratings for being market driven. }\end{array}$} \\
\hline \multicolumn{6}{|c|}{$\begin{array}{l}\text { a Unadjusted practice-level scores. } \\
{ }^{b} \text { Calculated using analysis of covariance with practice-averaged scores as the response variable, controlling for practice size. } \\
\text { 'Calculated using hierarchical models with staff members' responses as the response variable, controlling for staff member sex and role within the practice as well as } \\
\text { practice size. }\end{array}$} \\
\hline
\end{tabular}

recommended assessments for $\mathrm{HbA}_{1 \mathrm{c}}$, lipids, and microalbumin for patients with diabetes. As high lipids are a major contributor to excess mortality among individuals with diabetes, ${ }^{40}$ it is important that we found that patients in practices with NPs were more likely to be treated for high lipid levels and to attain lipid targets than their counterparts in practices with PAs. Better monitoring of $\mathrm{HbA}_{1 \mathrm{c}}$ and microalbumin levels did not appear to carry over to better treatment or control of these intermediate outcomes, however. Compared with physician-only practices, practices employing NPs were more likely to appropriately monitor $\mathrm{HbA}_{\mathrm{Ic}}$ and lipids, although again this did not translate into significantly better treatment or control. If verified in other studies, these results highlight the need for greater understanding of the many possible reasons for these differences as well as the reasons for the lack of a causal relationship between process and outcome measures.

This study had a number of limitations. First, this secondary analysis of baseline data from an intervention trial had relatively small numbers of practices with either NPs or PAs. The small sample size may have affected our ability to find significant differences in patient care or measured organizational characteristics. This small sample size combined with missing information on physician, practice, or patient characteristics may also have led to a failure to detect differences between the practices that may have served as confounders for the effect of practice type. Measuring additional variables may have provided more hints as to the reason for the differences found. For example, there may be additional confounders that we did not capture, including patient demographics such as socioeconomic status, additional physician demographics or patient care philosophies, or other measures of practice culture. In addition, we may not have measured components of care that are potentially most affected by collaboration with a diverse clinician base, such as behavioral counseling. Finally, this study may not be generalizable to all small family medicine practices for 2 reasons. First, this analysis focused on average trends and did not highlight individual practices, for example, those practices with PAs that did demonstrate good diabetes care. Second, the study included only a small number of practices in New Jersey and Pennsylvania that agreed to participate in a fairly intensive intervention trial.

Because this study was observational, we cannot conclude causation from any associations; furthermore, the study design precludes connection of patients with particular clinicians. Previous studies, including randomized trials, that have matched patients to specific midlevel and physician clinicians have found similar results for NPs, however. ${ }^{19,22}$ A strength of this study is that it examines the overall effect of teams of clinicians in family medicine practices on treating patients with diabetes. This approach is consistent with several major recommendations arguing that primary care practices should use teams of clinicians working together to treat populations of patients. ${ }^{3.5}$

Explanations for the results of this study may rest 
either with the NPs and PAs or with the practices that hire them, although we were unable to uncover literature that would support any particular explanation. On one hand, differences in training between $\mathrm{NPs}^{21,22}$ and $\mathrm{PAs}^{41}$ or the original selection of careers by individuals with different values may affect the care given and how these clinicians interact with other members of the practice. For example, PAs are trained to work in environments where they are supervised by physicians, whereas NPs may treat patients independently. In addition, NPs may add new perspectives within a team of clinicians because of their background in nursing as well as their emphasis on the well-being of the whole patient, prevention of illness, and patient education. ${ }^{21,22}$ Alternatively, the rationale that practices have for hiring and integrating a particular type of midlevel clinician may result in different models of care. For example, practices wishing to improve quality of care or adhere to a more holistic approach to medicine may tend to hire NPs, whereas those that want to increase patient volume may tend to hire PAs, although our analysis of our market orientation measures of the practices did not confirm this explanation. To conclusively exclude the latter explanation, one would need to conduct a randomized clinical trial in which NPs, PAs, or neither were randomly assigned to physician-only practices and followup data were used to study changes in care patterns.

We had hoped to identify explanations for these results by analyzing qualitative field notes from facilitators' observations and from key informant and indepth interviews of clinicians and staff collected in each practice at baseline for the ULTRA study. We hypothesized a priori that a confounding factor for the relationship between presence of NPs and improved guideline adherence was the level of practice cohesion, in the form of good communication, cross-training, shared decision making, and mutual respect of diverse roles. We selected 1 practice that performed well and 1 that performed poorly with respect to the diabetes care indicators from each of the 3 groups (physicianonly, practices employing NPs, and practices employing PAs) and blinded the analysts to the performance level of the practice. A careful analysis of these qualitative data, through the process of immersion and crystallization, ${ }^{42}$ was unable to confirm this hypothesis or identify other organizational features or patterns that differed among the types of practices.

Additional studies are needed with the primary intent of uncovering differences between practices, reasons why practices hire NPs and PAs, and processes by which those clinicians are integrated into practices. These studies should attempt to identify the best roles for different clinicians working in teams to maximize their impact on patient care. Further investigation into the distribution of patients and types of patient visits to clinician type may uncover reasons for differences among practices in the quality of adherence to diabetes assessment guidelines and attainment of lipid targets. For instance, when a practice uses either PAs or NPs, the practice's overall performance may reflect the distribution of patients to clinicians. Complex patient cases may be assigned to physicians, more routine or acute cases may be assigned to PAs, and cases requiring a more preventive approach may be assigned to NPs. Theoretically, this could lead to more efficient and individualized patient care.

In conclusion, family medicine practices with NPs performed better at providing some types of diabetes care (primarily monitoring tests) than physician-only practices and especially better than practices using PAs. With the burgeoning use of PAs and NPs in attempts to cut costs and try different models of clinical care, ${ }^{3-5}$ these results point to a need for additional research to confirm these associations and to explore their causes. Given the lack of literature examining the roles and contributions of both NPs and PAs within the context of family medicine practices, even additional descriptive studies would be helpful. Such studies should be part of the process of discovering how teams of clinicians that include midlevel practitioners can be used most effectively and efficiently in primary care practice.

To read or post commentaries in response to this article, see it online at http://www.annfammed.org/cgi/current/full/6/1/14.

Key words: Family medicine; nurse practitioners; physician assistants; diabetes mellitus; quality of health care; practices; professional practice; office visits; long-term care; disease management; patient care management

Submitted March 13, 2007; submitted, revised, July 25, 2007; accepted August 10, 2007.

An early version of this work was presented as a poster at the 2006 NAPCRG annual meeting, October 15-18, Tucson, Arizona.

Funding support: Data collection and analysis were supported by a grant from the National Heart, Lung, and Blood Institute (R01 HL70800) and an AAFP Research Center Grant. This research was also supported by the Cancer Institute of New Jersey's Primary Care Research shared resource.

Acknowledgments: We gratefully acknowledge the practices from the New Jersey Family Medicine Research Network and Eastern Pennsylvania Inquiry Collaborative Network, whose participation made this study possible.

\section{References}

1. Phillips RL, Green LA, Fryer GE, Dovey SM. Uncoordinated growth of the primary care work force. Am Fam Physician. 2001;64(9):1498.

2. Sherwood GD, Brown M, Fay V, Wardel D. Defining nurse practitioner scope of practice: expanding primary care services. Int J Adv Nurs Pract. 1998;1(2):1-12. http://ispub.com/ostia/index.php?xmlPrin ter=trueExmlFilePath=journals/ija np/vl1n. Accessed: July 27, 2006. 
3. Bodenheimer T, Wagner EH, Grumbach K. Improving primary care for patients with chronic illness - the chronic care model, part 2. JAMA. 2002;288(15):1909-1914.

4. Larson EB, Fihn SD, Kirk LM, et al. The future of general internal medicine-report and recommendations from the Society of General Internal Medicine (SGIM) task force on the domain of general internal medicine. J Gen Intern Med. 2004;19(1):69-77.

5. Martin JC, Avant RF, Bowman MA, et al. The Future of Family Medicine: a collaborative project of the family medicine community. Ann Fam Med. 2004;2(Suppl 1):s3-s32.

6. Wilson A, Pearson D, Hassey A. Barriers to developing the nurse practitioner role in primary care-the GP perspective. Fam Pract. 2002;19(6):641-646.

7. Flanagan L. Nursing practitioners: growing competition for family physicians? Fam Pract Manag. 1998;5(9):34-36, 41-43.

8. Carr J, Armstrong S, Hancock B, Bethea J. GPs' perceptions of the nurse practitioner role in primary care. Br J Community Nurs. 2002;7(8):408-413.

9. Mundinger MO, Kane RL, Lenz ER, et al. Primary care outcomes in patients treated by nurse practitioners or physicians - a randomized trial. JAMA. 2000;283(1):59-68.

10. Horrocks S, Anderson E, Salisbury C. Systematic review of whether nurse practitioners working in primary care can provide equivalent care to doctors. BMJ. 2002;324(7341):819-823.

11. Roblin DW, Becker ER, Adams EK, Howard DH, Roberts MH. Patient satisfaction with primary care: does type of practitioner matter? Med Care. 2004;42(6):579-590.

12. Cipher DJ, Hooker RS, Sekscenski E. Are older patients satisfied with physician assistants and nurse practitioners? JAAPA 2006;19(1):36, 39-40, 42-44.

13. Roblin DW, Howard DH, Becker ER, Kathleen Adams E, Roberts MH Use of midlevel practitioners to achieve labor cost savings in the primary care practice of an MCO. Health Serv Res. 2004;39(3):607-626.

14. Venning P, Durie A, Roland M, Roberts C, Leese B. Randomised controlled trial comparing cost effectiveness of general practitioners and nurse practitioners in primary care. BMJ. 2000;320(7241):1048-1053.

15. Kinnersley P, Anderson E, Parry K, et al. Randomised controlled trial of nurse practitioner versus general practitioner care for patients requesting "same day" consultations in primary care. BMJ. 2000;320(7241):1043-1048.

16. Sakr M, Angus J, Perrin J, Nixon C, Nicholl J, Wardrope J. Care of minor injuries by emergency nurse practitioners or junior doctors: a randomised controlled trial. Lancet. 1999;354(9187):1321-1326.

17. Hooker RS, McCaig LF. Use of physician assistants and nurse practitioners in primary care, 1995-1999. Health Aff (Millwood). 2001;20(4):231-238.

18. Running A, Kipp C, Mercer V. Prescriptive patterns of nurse practitioners and physicians. J Am Acad Nurse Pract. 2006;18(5):228-233.

19. Lenz ER, Mundinger MO, Hopkins SC, Lin SX, Smolowitz JL. Diabetes care processes and outcomes in patients treated by nurse practitioners or physicians. Diabetes Educ. 2002;28(4):590-598.

20. Cintron G, Bigas C, Linares E, Aranda JM, Hernandez E. Nurse practitioner role in a chronic congestive heart-failure clinic-in-hospital time, costs, and patient satisfaction. Heart Lung. 1983;12(3):237-240.

21. Shuler PA, Huebscher R. Clarifying nurse practitioners' unique contributions: application of the Shuler Nurse Practitioner Practice Model. J Am Acad Nurse Pract. 1998;10(11):491-499.

22. Hopkins SC, Lenz ER, Pontes NM, Lin SX, Mundinger MO. Context of care or provider training: the impact on preventive screening practices. Prev Med. 2005;40(6):718-724.
23. Safriet B. Health care dollars and regulatory sense: the role of advanced practice nursing. Yale J Regul. 1992;9(2):417-487.

24. Laurant M, Reeves D, Hermens R, Braspenning J, Grol R, Sibbald B. Substitution of doctors by nurses in primary care. Cochrane Database System Rev. 2005;Apr 18(2):CD001271.

25. Edmondson AC. Speaking up in the operating room: how team leaders promote learning in interdisciplinary action teams. J Manage Stud. 2003;40(6):1419-1452.

26. Cohen D, McDaniel RR, Crabtree BF, et al. A practice change model for quality improvement in primary care practice. J Healthc Manag. 2004;49(3):155-168.

27. Tallia AF, Lanham HJ, McDaniel RR Jr, Crabtree BF. 7 characteristics of successful work relationships. Fam Pract Manag. 2006;13(1):47-50.

28. Zazworsky D, Bolin J, Gaubeca VB. Handbook of Diabetes Management. New York, NY: Springer; 2006.

29. Grant RW, Pirraglia PA, Meigs JB, Singer DE. Trends in complexity of diabetes care in the United States from 1991 to 2000. Arch Intern Med. 2004;164(10):1134-1139.

30. Peterson KA. Diabetes management in the primary care setting: summary. Am J Med. 2002;113(Suppl 6A):36S-40S.

31. Stroebel CK, McDaniel RR Jr, Crabtree BF, Miller WL, Nutting PA, Stange KC. How complexity science can inform a reflective process for improvement in primary care practices. Jt Comm J Qual Patient Saf. 2005;31(8):438-446

32. Ohman-Strickland PA, Orzano AJ, Nutting PA, et al. Measuring organizational performance attributes of primary care practices: development of a new instrument. Health Serv Res. 2007;42 (3 Pt 1):1257-1273.

33. Quinn RE. Beyond Rational Management: Mastering the Paradoxes and Competing Demands of High Performance. 1st ed. San Francisco, CA: Jossey-Bass; 1988.

34. Shortell SM, Jones RH, Rademaker AW, et al. Assessing the impact of total quality management and organizational culture on multiple outcomes of care for coronary artery bypass graft surgery patients. Med Care. 2000;38(2):207-217.

35. American Diabetes Association Clinical Practice Recommendations 2001. Diabetes Care. 2001;24(Suppl 1):S1-S133.

36. SAS Institute Inc. SAS/STAT 9.1 User's Guide. Cary, NC: SAS Institute Inc; 2004.

37. Hochberg Y, Tamhane AC. Multiple Comparison Procedures. Wiley Series in Probability and Mathematical Statistics. Applied Probability and Statistics. New York, NY: Wiley; 1987:xxii, 450.

38. Raghunathan TE, Lekowski JM, Van Hoewyk J, Solenberger P. A multivariate technique for multiply imputing missing values using a sequence of regression models. Surv Method. 2001;27(1):85-95

39. Raghunathan TE, Solenberger P, Van Hoewyk J. IVEware: Imputation and Variance Estimation Software. Ann Arbor, MI: Survey Methodology Program, Survey Research Center, Institute for Social Research, University of Michigan; 2002.

40. Snow V, Aronson MD, Hornbake ER, Mottur-Pilson C, Weiss KB Lipid control in the management of type 2 diabetes mellitus: a clinical practice guideline from the American College of Physicians. Ann Intern Med. 2004;140(8):644-649.

41. Jones PE, Cawley JF. Physician assistants and health system reform. Clinical capabilities, practice activities, and potential roles. JAMA. 1994;271(16):1266-1272.

42. Borkan J. Immersion/crystallization. In: Crabtree BF, Miller WL, eds. Doing Qualitative Research. 2nd ed. Thousand Oaks, CA: Sage Publications; 1999:179-194. 